\title{
Research on the Shaping Path of Government Image From the Government New Media
}

\author{
$\mathrm{Li} \mathrm{Luo}{ }^{1, *}$ Kexin $\mathrm{Hu}^{2}$
}

\begin{abstract}
${ }^{1}$ School of Public Affairs \& Law, Southwest Jiaotong University, Chengdu, Sichuan, China
${ }^{2}$ Chengdu City Road and Bridge Supervision Service Center, Chengdu, Sichuan, China

*Corresponding author. Email: luoli125@foxmail.com
\end{abstract}

\begin{abstract}
The government new media as the "bridge" between the government and the public is an important platform for shaping the image of the government. The investigation showed that the use of the government new media needs to be improved, the public participation rate is low, and the public preferences are diversified. Information release, service provision and communication and interaction are taken as evaluation indicators and shaping paths for the government image of new government media. The strategy to enhance the government's image is to improve the quality of information dissemination, broaden service channels, strengthen interactive communication, improve technology, and enhance the quality of public servants. On the other hand, we should encourage the public to actively participate in politics and cultivate their political interest.
\end{abstract}

Keywords: administration, government new media, public, government image

\section{INTRODUCTION}

According to the 44th statistical report on the development of Internet in China, as of June 2019, the scale of netizens reached 854 million, with the penetration rate reaching $61.2 \%$, among them, the scale of mobile netizens reached 847 million. The extensive use of new media has led to the explosive dissemination of network information, which has led to frequent network crises and emergence of rumors, bringing great challenges to government management and social stability. (P.Q. Han, 2016) What's more, China had 509 million online government service users, accounting for $60 \%$ of the total number of Internet users. And 297 prefectural-level cities had their official accounts on micro-blog, we-chat and other new media platforms, with a coverage rate of $88.9 \%$. The government new media has become an important part of the trend of China's Internet public opinion pattern and a "golden key" to enhance the ability of national governance. So, how to make good use of new government media to expand the government's influence and establish a positive government image is the main research question of this article, which is worthy of further consideration.

\section{Methodology}

\section{A. Overall research framework}

This paper uses the method of questionnaire and interview to understand the relevant situation of the government new media and government evaluation, and then describes the status quo through statistical analysis of the data. Investigations are conducted from both the government and the public. Taking Cuiping District as the research object, it includes government propaganda department and the public, to understand the construction and use of new government media.

\section{B. Government new media and government image}

Government new media refers to the new media platform for government agencies to carry out their works, provide public products and services, communicate with the public and ask for government affairs online, including government micro-blog, government We-Chat, government information app, and so on.

The image of the government is the public's comprehensive understanding of the government, based on government's actions and public's evaluation, which is subjective, dynamic and diverse. (N.S. Hu, 1998) The government image building is a process of interaction between the government and the public, which means that the government establishes its image by influencing the public's evaluation of the government. (L. Chen, 2017)

\section{The shaping path of local government image}

Network governance is a process in which government and non-government cooperate to share public power in an interdependent environment and manage public affairs jointly in order to promote public 
interests. It embodies cooperative management. (Z.M. Chen, 2005) and some pointed out there are three elements in government public relations: government, public and intermediary (W.Y. Xiong, 1990). According to the theoretical, the path of government image shaping is divided into information dissemination, service-provision, communication interaction, which is also the evaluation index of government image. (B.H. Jiang, 2018)

1) Information release: The right to know is the basic right of citizens, so information dissemination is the primary function of new government media and the key to building a transparent government. It plays an irreplaceable role in promoting government information disclosure and guiding public opinion on social networks. And it also promotes the modernization of national governance system and governance capacity to a certain extent. The dissemination of information can publicize the image of the government, help citizens understand the government, and play a certain role in public evaluation and recognition.

2) Service provision: Government use new media technologies to provide convenient services towards the public, and enhance its service ability by using more online convenience services, which is a powerful way to shape the image of the government. Only in this way can the public be truly satisfied.

3) Communication interaction: The new media of government affairs breaks the one-way communication of traditional media, strives to communicate with the masses, realizes interactive feedback timely, and realize the image management in a dynamic manner. What's more, the communication and interaction on the new media is also one of the ways for the public to realize online political participation, which enlarges the channels for citizens to participate in political discussion. On the other hand, it strengthens the supervision of the masses over the government and promotes the construction of a transparent, legal and efficient government.

\section{Data collection}

Yibin City, as the study area of this paper, is located in the southwest of Sichuan Province. The data comes from previous academic papers on new media reports, with a total of 172 valid questionnaires. The questionnaire consists of 18 questions, three parts. Firstly, basic information will be based on gender, age, profession, etc. Then, the condition includes the use of new government media, the frequency of participation and interaction, and information preference. Finally, it is the overall evaluation of the new government media and the government.

\section{E. Data analysis}

First, we start with the basic information of the questionnaire. In the valid questionnaire results of this survey, there were 84 males and 88 females, with the age of $59.30 \%$ at the 20-29 stage, followed by $30-39$ and 40-49 stages. The education background is rather scattered, with most of the educational level concentrated in the undergraduate education of $51.46 \%$. In the profession, students are the most, followed by farmers, workers and civil servants, satisfying the random distribution of objects.

In the question of "Which of the following factors can most affect your evaluation of local government", and there are 172 valid questionnaires, 101 choose "provide services" and 100 choose "staff", which shows that these two factors can most affect the public's evaluation, while information disclosure, government policy, and interaction with the public account for very little.

Starting from the two questions of "the frequency of your use of new media" and "the frequency of your use of new media for government affairs", this part analyses the relationship between the use of new media and new government media. We can see that the use of new media is mostly concentrated in very frequent and more, accounting for $72.09 \%$, while the use of new media for government affairs is mostly concentrated in general and less, accounting for $69.19 \%$. It is not surprising to draw such a conclusion. Compared with the public's use of new media, the government new media may drop by a level, because the former is selected according to their own interests and needs on the basis of the latter's use.

In "Do you agree with the government new media in promoting government information dissemination, service-provision and communication interaction?", the date have shown the majority of them are agree, while the proportion of disagreement is very small. It can be seen simply that most people agree with the role of government new media in promoting information dissemination, service-provision and communication interaction.

\section{RESUlTS}

\section{A. The operation and management of new government media}

According to the interview in the Cuiping, we know the new government media are "two micro-one newspaper", "Cuiping Publishing" official micro-blog, "Sanjiang Cuiping" We-chat Official Account and Cuiping Mobile Newspaper. There are more than 30,000 subscribers in micro-blog and We-Chat. Mobile phone newspapers are sent to the mobile phones of all residents in Cuiping District. It's based on the 
communication, service and interaction of the new government media and involves user coverage, message publishing mechanism, service status and interactive forms, etc. We can understand the basic operation of the new government media in Cuiping District.

In general, the content of the new government media in Cuiping District is narrow and does not fit the needs of the public. Secondly, there is a lack of special government APP and a single type of service. Then, the author browses the past information of micro-blog and We-Chat and finds that the daily reading volume is higher than the interaction rate, and the interaction rate is low, with a large number of "zombie fans". Finally, during the interview, it was also found that the government staff was not familiar with the goal of shaping the government image.

\section{B. The use of new government media}

The widespread use of new media will promote the use and development of new government media. But in this process, it will undoubtedly be affected by age, education background, professional and political knowledge interest. Among them, age affects users' use of smart phones, and the use habits of mobile phones have a certain relationship with the education background. The higher the level of knowledge, the more targeted the use of mobile phones. Professional differences mean that people pay different attention to new media. People working in institutions and stateowned enterprises will pay more attention to new media. Finally the interest in political knowledge is to promote the use of new government media on the basis of the use of new media. Therefore, these factors will affect the use of new government media to a certain extent.

\section{DISCUSSION}

We will discuss how to make better use of new government media to achieve good-governance from the perspective of the government and the public.

\section{A. The government}

1) Improving the quality of information dissemination: the information construction is the main work of the government, such as demonstrations around, voluntary felon-fighting, community and township activities, poverty alleviation columns, etc. From the point of view of functional and preference surveys, attention should also be given to the reporting of public events, events, processes and results so as not to create mistrust among the population. The media should not only report the positive image of the government, but also pay attention to the shortcomings of the government and how to deal with it, so as to promote transparency, fairness and openness.

2) Emphasizing on service function development and broadening service channels: Currently, it also lacks a special government application to provide services, far from the service effectiveness of the government website. With the media develop gradually, we can consider developing and utilizing government affairs APP to achieve centralized gathering of various services, broaden service functions, and provide more convenience for the masses.

3) Strengthening interactive communication and promoting government dialogue and consultation: Although Cuiping District will hold online interactive activities of new government media, but the enthusiasm of the masses will only increase during the event, and the general participation rate is low. The government should consider the interaction rate in content editing, and regularly assess the interaction rate. It is necessary to innovate in publishing news, to stimulate public participation enthusiasm, to improve the enthusiasm of the people to participate in politics, to conduct interactive feedback, and to expand the influence of the government.

4) Improving government affairs and new media technology: The forms of new media are gradually diversifying, and the public's requirements for new government media are getting higher and higher. Therefore, the media should keep up with the pace of development and innovate and improve timely. At the same time, it should also be assessed, evaluated and improved according to the actual application of the local area. The government should improve the technology, and then create distinctive, highly recognized, unique style of new government media to promote the government's positive image dissemination.

5) Improving the quality of civil servants: The quality of manager in new media will directly affect the operation process and even the whole operation status, thus affecting public awareness and image-building of the government. Therefore, it is necessary urgently to strengthen the study and training of political knowledge, network communication mechanism, strategic positioning of the government and operation mechanism of the media. Only by grasping the source of the dissemination and effectively operating, can we rationally improve and strengthen the public's evaluation of the government.

\section{B. The public}

It can be seen from the above survey results that there is still a lot of room for improvement in the use 
and interaction of new media by the public. As the main body, the public is important to shape the image of government. First, it must learn political knowledge, care about the policies of the national government, improve its political quality, and participate in politics actively, so as to ensure the basic participation of citizens in political rights. Secondly, the public, as a user of new media, must treat network information rationally, refuse rumors, treat public opinion dialectically, take correct channels to reflect demands to the government, and strengthen interaction and communication with new government media. Finally, citizens must communicate with the government actively, express their needs and feedback, in order to better promote the development of government, improve the quality of the service, and realize the value of government. Only when the government and the public achieve effective communication and joint promotion can a country ensure the country's prosperity, democracy, and realize the building of a socialist modernization.

\section{CONCLUSION}

This paper discusses how the government and the public should act in the new government media, and how the government can establish a good image through the new government media. The conclusion is that the government should start from the three aspects of information dissemination, service provision, and communication and interaction; the public should strengthen their own enthusiasm for political participation and maintain rationality. Finally, a virtuous circle can be realized.

But this article also lacks the illustration of the typical case facts of the successful image through the new government media, and cannot directly understand the relationship between the two. If there is an opportunity, we will start from every process of communication between the government and the public, analyze the factors that affect the dissemination of the image of the government in detail in each process, so as to avoid misleading dissemination.

\section{References}

[1] B.H.Jiang. Current situation and Countermeasures of new media for government affairs [J]. New media research, 2018, 4 (05): 51-52.

[2] China Internet Information Center. 44th Statistical Report on the Development of Internet in China [EB/OL]. [2019-08-29]. http://www.cac.gov.cn/2019-08/30/c_1124939590. htm

[3] L.Chen. Research on Government Image-building from the Perspective of Government Public Relations [J]. News Knowledge, 2017, 06:73-76.

[4] N.S.Hu. Image Strategy of the Chinese Government [M]. Beijing: Party School Press of the CPC Central Committee, 1998:148.
[5] P.Q.Han. On the Challenges and Opportunities of Government Image Construction in the Age of Self-Media [J]. China Newspaper Industry, 2016, 16:30-31.

[6] Y.W.Xiong. Public Relations [M]. Anhui: Anhui People's Publishing House, 1990:12.

[7] Z.M.Chen. Public Management (The First Edition) [M] Beijing: Renmin University Press, 2005:78-82. 